\title{
LC-ESI-MS Analysis, Antitumor and Antiviral Activities of Bosica senegalensis Aqueous Methanolic Extract
}

\author{
Ahmed Elkhateeb*, Sameh R. Hussein, Maha M. Salem, Sabry I.M. EI Negoumy \\ Department of Phytochemistry and Plant Systematics, National Research Centre, 33 \\ El Bohouth St., Dokki, P. O. 12622, Giza, Egypt.
}

\begin{abstract}
7 WENTY ONE compounds (twelve flavonoids, four benzoylglucarate isomers, two phenolic 1 acids, two glucosinolates, and one saccharide) were identified from the B. senegalensis aqueous methanolic extract using LC-ESI-MS technique. Among the identified compounds, quercetin- $O$-sinapoylglucoside- $O$-glucoside (13) and quercetin-di- $O$-benzoyl glucoside (16) are newly identified natural products.
\end{abstract}

B. senegalensis aqueous methanolic extract showed strong inhibitory effect against H5N1 viruses and moderate antitumor activity against three carcinoma cell lines.

Keywords: Boscia senegalensis, Capparaceae, LC-ESI-MS, Antitumor, Antiviral.

\section{Introduction}

The genus Boscia Lam. belongs to family Capparaceae comprises of approximately 37 species mainly distributed in tropical and Southern Africa except (B. arabica Pest.) distributed in southern Arabia [1, 2].

Boscia senegalensis (Pers.) Lam. ex Poir. is an evergreen shrub reaching $7 \mathrm{~m}$ in height and distributed throughout Gabel Elba, Egypt; Northcentral and northern Senegal [3], the importance of the plant for the rural agro-economy in Africa for both human and animals [4] where it is traditionally used by farmers against stored grain insects. The biological activity of the plant is due to the liberation of MITC (methlyisothiocyanate) from a glucosinolate precursor glucocapparin contained in Boscia fruits and leaves. The introduction of the released MITC from $B$. senegalensis in the storage systems decreases the density of the population of parasites and increases the seed losses by allowing the development of the bruchid population [5].

Although the fruit of $B$. senegalensis is highly acidic; it is used for human consumption and becomes edible after soaking in water for seven days [6]. In Sudan, it is fermented into beer, while the leaves are used in food preservation against parasites [6].
Dried bark and leaves are used for schistosomiasis, while the leaves extract is used as eyewash seeds have antidiabetic properties mainly due to its high content of glucocapparin [6].

Phytochemical studies on B. senegalensis conducted on the leaves and fruits identified glucosinolate (methyl, 2-propyl, and 2-butylglucosinolate) [7], flavonol glycosides, megastigmane, monoterpenes, phenolic compounds and lignan [8].

The aim of the current study is to profile the phytochemical constituents of $B$. Senegalensis aqueous methanolic extract using LC-ESI-MS; in addition to investigating its antitumor and antiviral activities.

\section{Experimental}

\section{Plant material}

The leaves of $B$. senegalensis were collected from Gebel Elba, south of Egypt on March 2016. The authentication of plant sample was achieved by Prof. Dr. Salwa Kawashty, Phytochemistry and Plant Systematics Department. A voucher specimen (s.n SK 860), was deposited in the herbarium of National Research Center (CAIRO).

Human tumor cell lines

Human tumor cell line; Breast (MCF7), liver (HEPG2) and colon (HCT) were obtained from

*Corresponding author e-mail: elkhateeb.ahmed@gmail.com; Tel: +20 1116757520

DOI: $10.21608 /$ ejchem.2018.4828.1428

C2017 National Information and Documentation Center (NIDOC) 
the American Type Culture Collection (ATCC, Minnesota, USA). The tumor cell lines were maintained at the National Cancer Institute, Cairo, Egypt by serial sub-cultures.

\section{Preparation of extracts for bioassay}

Stock solutions of the tested extract were dissolved as $0.1 \mathrm{~g}$ in $1 \mathrm{ml}$ of $10 \%$ Dimethyl Sulfoxide (DMSO) in deionized water. The prepared extract solution was used for both cytotoxicity and antiviral bioassays.

MTT cytotoxicity and determinate assay $\left(T C_{50}\right)$

Samples were 10-fold serially diluted with Dulbecco's Modified Eagle's Medium (DMEM). Stock solutions of the test extract were prepared in $10 \% \mathrm{DMSO}$ in $\mathrm{ddH}_{2} \mathrm{O}$. The cytotoxic activity of the extract was tested in Madin Darby Canine kidney (MDCK) cells by using the 3-(4, 5-dimethylthiazol -2-yl)-2, 5-diphenyltetrazolium bromide (MTT) method [9] with minor modification. Briefly, the cells were seeded in 96 well-plates $(100 \mu \mathrm{l} /$ well at a density of $3 \times 10^{\wedge} 5$ cells $/ \mathrm{ml}$ ) and incubated for $24 \mathrm{hr}$ at $37^{\circ} \mathrm{C}$ in $5 \% \mathrm{CO}_{2}$. After $24 \mathrm{hr}$, cells were treated with various concentrations of the tested compounds in triplicates. After further $24 \mathrm{hr}$, the supernatant was discarded and cell monolayers were washed with sterile phosphate buffer saline (PBS) 3 times and MTT solution ( $20 \mu \mathrm{l}$ of $5 \mathrm{mg} / \mathrm{ml}$ stock solution) was added to each well and incubated at $37{ }^{\circ} \mathrm{C}$ for $4 \mathrm{hrs}$ followed by medium aspiration. In each well, the formed formazan crystals were dissolved with $200 \mu$ l of acidified isopropanol (0.04 $\mathrm{M} \mathrm{HCl}$ in absolute isopropanol $=0.073 \mathrm{ml} \mathrm{HCl}$ in $50 \mathrm{ml}$ isopropanol). The absorbance of formazan solutions was measured at $\lambda_{\max } 540 \mathrm{~nm}$ with $620 \mathrm{~nm}$ as a reference wavelength using a multi-well plate reader. The percentage of cytotoxicity compared to the untreated cells was determined as follows: $\%$ of cytotoxicity $=[($ Absorbance of cell without treatment - Absorbance of cell with treatment)/ Absorbance of cell without treatment] $\times 100$. The plot of $\%$ cytotoxicity versus sample concentration was used to calculate the concentration which exhibited $50 \%$ cytotoxicity $\left(\mathrm{TC}_{50}\right)$.

\section{Plaque reduction assay}

Anti-H5N1 activity of the extract of $B$. senegalensis was investigated by plaque reduction assay with confluent 24 h old monolayer of MDCK cells. Assay was carried out according to the reported methods [10]. In a six well plate where MDCK cells $\left(10^{\wedge} 5\right.$ cells $\left./ \mathrm{ml}\right)$ were cultivated for $24 \mathrm{hrs}$ at $37^{\circ} \mathrm{C}$. A/Chicken/Egypt/M7217B/2013 (H5N1) virus was diluted to give $104 \mathrm{PFU} /$ well and mixed with the safe concentrations of the tested compounds and incubated for 1 hour at $37^{\circ} \mathrm{C}$ before being added to the cells. Growth medium was removed from the cell culture plates and virus-Cpd or virus-extract and Virus-Zanamivir mixtures were inoculated (100 $\mu \mathrm{l} /$ well). After 1 hour contact time for virus adsorption, $3 \mathrm{ml}$ of DMEM supplemented with $2 \%$ agarose was added into the cell monolayer, plates were left to solidify and incubated at $37^{\circ} \mathrm{C}$ till formation of viral plaques ( 3 to 4 days). Formalin (10\%) was added for two hours then plates were stained with $0.1 \%$ crystal violet in distilled water. Control wells were included where untreated virus was incubated with MDCK cells and finally plaques were counted and percentage reduction in plaques formation in comparison to control wells was recorded as follows: \% of inhibition= [viral count (untreated) - viral count (treated)/viral count (untreated) $] \times 100$.

\section{Assay of the antitumor activity \\ Principle}

The cytotoxicity was carried out using Sulphorhodamine-B (SRB) assay following the method reported by Vichai and Kirtikara [11]. $\mathrm{SRB}$ is a right pink aminoxanthrene dye with two sulphonic groups. It is a protein stain that binds to the amino groups of intracellular proteins under mildly acidic conditions to provide a sensitive index of cellular protein content.

\section{Procedure}

Cells were seeded in 96-well microtiter plates at initial concentration of $3 \times 10^{3}$ cell/well in a 150 $\mu \mathrm{l}$ fresh medium and left for 24 hours to attach to the plates. Different concentrations $0,5,12.5$, $25,50 \mu \mathrm{g} / \mathrm{ml}$ of drug were added. For each drug concentration, 3 wells were used. The plates were incubated for 48 hours. The cells were fixed with $50 \mu 1$ cold trichloroacetic acid $10 \%$ final concentration for 1 hour at $4{ }^{\circ} \mathrm{C}$. The plates were washed with distilled water using (automatic washer Tecan, Germany) and stained with $50 \mu \mathrm{l}$ $0.4 \%$ SRB dissolved in $1 \%$ acetic acid for 30 minutes at room temperature. The plates were washed with $1 \%$ acetic acid and air-dried. The dye was solubilized with $100 \mu \mathrm{l} /$ well of $10 \mathrm{M}$ tris base (pH 10.5) and optical density (O.D.) of each well was measured spectrophotometrically at 570 nm with an ELISA microplate reader (Sunrise Tecan reader, Germany). The mean background absorbances was automatically subtracted and mean values of each drug concentration was calculated. The percentage of cell survival was calculated as follows: Surviving fraction $=$ O.D.

Egypt. J. Chem. 62, No. 1 (2019) 
(treated cells)/ O.D. (control cells). The $\mathrm{IC}_{50}$ values (the concentrations of drug required to produce $50 \%$ inhibition of cell growth) were also calculated.

\section{Extraction Process}

The fresh leaves of $B$. senegalensis $(1.15 \mathrm{~kg})$ were air dried in shad and ground, then extracted three times at room temperature with $70 \%$ methanol/water. The aqueous methanol extract was evaporated under reduced pressure and temperature to obtain a residue of $204 \mathrm{~g}$.

\section{Acid hydrolysis}

Acid hydrolysis was carried out for 60 minutes at $100{ }^{\circ} \mathrm{C}$ using $2 \mathrm{~N}$ hydrochloric acid. The yielded aglycones were then extracted with ethyl acetate and identified by co-chromatography with stander samples; while the sugars obtained by hydrolysis of the flavonoid glycosides were identified by PC using BBPW (Benzene: n-butane: pyridine: water; $1: 5: 3: 3)$, with a standard sugar mixture. The dried chromatograms were visualized by aniline phthalate reagent. The sugar spots were observed in daylight. The $R_{f}$ values of tested sugars were compared with those of reference sugars.

\section{LC-ESI-MS Analysis}

LC-ESI-MS analysis: HPLC (Waters Alliance 2695) and MS spectrometry (Waters 3100). The defatted $70 \%$ methanol extract of $B$. sensgalensis solution $(5 \mathrm{mg} / \mathrm{ml})$ was prepared in HPLC grade solvent mixture of $\mathrm{CH}_{3} \mathrm{CN} / \mathrm{MeOH} / \mathrm{H}_{2} \mathrm{O}(1: 1: 2$; $v / v / v)$ and filtered using membrane disc filter $(0.45 \mu \mathrm{m})$ and prepared for qualitative analysis. The mobile phase was prepared daily by filtering through $0.45 \mathrm{~m}$ membrane disc filter and degassed by sonication before use. The mobile phase for gradient elution consists of two solvents: solvent A $\left(0.1 \%\right.$ formic acid (FA) in $\left.\mathrm{H}_{2} \mathrm{O}\right)$ and solvent $\mathrm{B}$ $\left(0.1 \% \mathrm{FA}\right.$ in $\left.\mathrm{CH}_{3} \mathrm{CN} / \mathrm{MeOH}(1: 1 ; v / v)\right)$. The linear gradient profile was as follows: $95 \%$ A $(5 \mathrm{~min})$, $95-90 \%$ A (10 min), 90-50\% A (55 min), 50-95\% $\mathrm{A}(65 \mathrm{~min})$, and $95 \% \mathrm{~A}(70 \mathrm{~min})$. The injection volume was $10 \mathrm{~L}$. The flow rate $(0.6 \mathrm{ml} / \mathrm{min})$ was split 1:1 before the MS interface. The negative ion mode parameters were as follows: source temperature $1503^{\circ} \mathrm{C}$, desolvation temperature $350^{\circ} \mathrm{C}$, cone gas flow $50 \mathrm{~L} / \mathrm{h}$, cone voltage 50 $\mathrm{eV}$, capillary voltage $3 \mathrm{kV}$, and desolvation gas flow $600 \mathrm{~L} / \mathrm{h}$. Spectra were recorded in the ESI negative mode between 170/ 50-1000. The peaks and spectra were processed using the Maslynx 4.1 software. Unknown peak was tentatively identified by comparing its retention time and mass spectrum with literatures. Known peak was identified by comparing its retention time $\left(t_{R}\right)$ and mass spectrum with a known standard.

\section{Results and Discussion}

Acid hydrolysis

The co-chromatography of the ethyl acetate extract gave three yellow spots under UV, indicating the flavonol nucleolus, and has the same $R_{f}$ of rhamnocetrin, quercetin and rhamnetin aglycones. Glucose and rhamnose were detected as sugar moieties in the aqueous extract. The complete acid hydrolysis indicated that all glycosides were in $O$-glycoside form.

\section{LC-ESI-MS analysis}

Plant extracts generally occur as a combination of different types of phytochemicals or biologically active compounds with different polarities, their isolation and identification remain a big challenge. Liquid chromatography mass spectrometry (LC-MS) is a powerful and new technique for identification of the complex botanical extracts [12]. It provides information for structural elucidation of the components of these extracts. Therefore, in the present work, the defatted $70 \%$ methanolic extract of $B$. senegalensis was subjected to HPLC coupled with MS spectrometry in negative ion mode (Fig. 1). The identification of the components of the extract was carried out through their retention times, molecular weights (MW), calculated $\mathrm{m} / \mathrm{z}$ and major fragments which produced under the ionization conditions, as well as by comparison of these data with the previously reported data in the literatures.

Twenty one compounds were identified from the $B$. senegalensis aqueous methanolic extract (Table1, Fig. 1) using LC-ESI-MS technique. Peaks 1 and 7 which appeared with molecular ion peak at $m / z 341,325$ respectively, are phenolic acid glycosides, after the loss of hexose moiety and the presence of fragments at $m / z 179,163$ indicated that compound $\mathbf{1}$ is identified as caffeic acid glucoside while 7 is coumaric acid glucoside [13, 14]. Peaks 2 and $\mathbf{3}$ have the same molecular ion peak at $\mathrm{m} / \mathrm{z} 412$ and identified as glucocapparine sulfate isomers which confirmed by their fragmentation patterns in the literature [15]. Four benzoylglucarate isomers $(4-6,8)$ were identified by their pseudomolecular ions at $\mathrm{m} / z 313$ [M-H] and its product ions at $\mathrm{m} / \mathrm{z} 191$ [M-H-benzoic acid]', 147, 85 [16]. Peak 9 with molecular ion peak at $\mathrm{m} / \mathrm{z} 371$ and its fragments is in agreement with Kang et al., [17] and identified 
as saccharide.

Peaks 10-22 were recognized as flavonol glycoside compounds. The fragments of peaks 10, 11, 13, 14 and 16 are characterized for quercetin nucleus, the appearance of peak $\mathbf{1 0}$ with pseudomolecular ion at $m / z 625[\mathrm{M}-\mathrm{H}]^{-}$and its fragments at $m / z 463$ [M-H-162] after the loss of glucose followed by $m / z 301$ [M-H-2×162] with another loss of glucose sugar, indicated that the glucoside moieties are in two different positions. In the same manner and in comparison with authentic stander and literature, compound $11 \mathrm{~m} / \mathrm{z}$
609 was identified as quercetin-3- $O$-glucoside-7$O$-rhmnaoside [18] while compound $14 \mathrm{~m} / \mathrm{z} 771$ was identified as quercetin-di- $O$-glucoside- $O$ rhmnaoside. Peak 13 have pseudomolecular ion peak at $m / z 831[\mathrm{M}-\mathrm{H}]$, gave fragment ions $\mathrm{m} / \mathrm{z}$ 669 [M-H-162] $^{-}$after loss of glucose, $\mathrm{m} / \mathrm{z} 463$ [M-H-162-206] after loss of sinapic acid and $\mathrm{m} / \mathrm{z}$ 301[M-H-162-206-162] withdrawing of another glucose suggesting that compound $\mathbf{1 3}$ could be assigned as quercetin- $O$-sinapoylglucoside$O$-glucoside. Peak 16 identified as quercetindi-O-benzoyl glucoside and appears with

TABLE 1. Phenolic compounds identified in $70 \%$ methanolic extract of $B$. senegalensis by LC-ESI (-ve)-MS.

\begin{tabular}{|c|c|c|c|c|c|}
\hline Peak no. & $t_{R}(\min )$ & M & {$[\mathrm{M}-\mathrm{H}]^{-}$} & $m / z$ fragments & Tentative identification \\
\hline 1 & 2.84 & 342 & 341 & 179 & Caffeic acid glucoside \\
\hline 2 & 3.26 & 413 & 412 & $332,259,241,97,96,75$ & $\begin{array}{l}\text { Glucocapparine sulfate (isomer } \\
\text { I) }\end{array}$ \\
\hline 3 & 3.92 & 413 & 412 & $332,259,241,97,96,75$ & $\begin{array}{l}\text { Glucocapparine sulfate (isomer } \\
\text { II) }\end{array}$ \\
\hline 4 & 14.78 & 314 & 313 & $191,147,85$ & Benzoylglucarate (isomer I) \\
\hline 5 & 18.87 & 314 & 313 & $191,147,85$ & Benzoylglucarate (isomer II) \\
\hline 6 & 19.96 & 314 & 313 & $191,147,85$ & Benzoylglucarate (isomer III) \\
\hline 7 & 22.63 & 326 & 325 & $185,163,119$ & Coumaric acid glucoside \\
\hline 8 & 24.47 & 314 & 313 & $191,147,85$ & Benzoylglucarate (isomer IV) \\
\hline 9 & 29.31 & 372 & 371 & $249,231,121,113$ & Saccharide \\
\hline 10 & 31.23 & 626 & 625 & 463,301 & Quercetin-di- $O$ - glucoside \\
\hline 11 & 31.65 & 610 & 609 & 463,301 & $\begin{array}{l}\text { Quercetin- } O \text { - glucoside- } \\
O \text {-rhmnaoside }\end{array}$ \\
\hline 12 & 32.23 & 640 & 639 & $477,315,301$ & Rhamentin-di- $O$-glucoside \\
\hline 13 & 40.08 & 832 & 831 & $669,463,301$ & $\begin{array}{l}\text { Quercetin- } O \text {-sinapoyl glucoside } \\
\text { - } O \text {-glucoside }\end{array}$ \\
\hline 14 & 40.75 & 772 & 771 & $609,463,301$ & $\begin{array}{l}\text { Quercetin-di- } O \text {-glucoside- } O \text { - } \\
\text { rhamnoside }\end{array}$ \\
\hline 15 & 41.75 & 786 & 785 & $623,477,315$ & $\begin{array}{l}\text { Rhamentin-di- } O \text { - glucoside- } O \text { - } \\
\text { rhmanoside }\end{array}$ \\
\hline 16 & 42.92 & 834 & 833 & $729,567,463,301$ & $\begin{array}{l}\text { Quercetin-di- } O \text {-benzoyl } \\
\text { glucoside }\end{array}$ \\
\hline 17 & 43.59 & 744 & 743 & $625,463,301$ & Unknown \\
\hline 18 & 46.68 & 608 & 607 & 299 & Rhamnocitrin- $O$-rutinoside \\
\hline 19 & 47.85 & 800 & 799 & $637,461,299$ & $\begin{array}{l}\text { Rhmanocitrin- } O \text {-feruloyl } \\
\text { glucoside } O \text {-glucoside }\end{array}$ \\
\hline 20 & 48.51 & 770 & 769 & 607,299 & $\begin{array}{l}\text { Rhmanocitrin- } O \text {-coumaroyl } \\
\text { glucoside - } O \text { - glucoside }\end{array}$ \\
\hline 21 & 50.60 & 462 & 461 & 299 & Rhmanocitrin- $O$ - glucoside \\
\hline 22 & 53.36 & 608 & 607 & 461,299 & $\begin{array}{l}\text { Rhmanocitrin- } O \text {-coumaroyl } \\
\text { glucoside }\end{array}$ \\
\hline
\end{tabular}




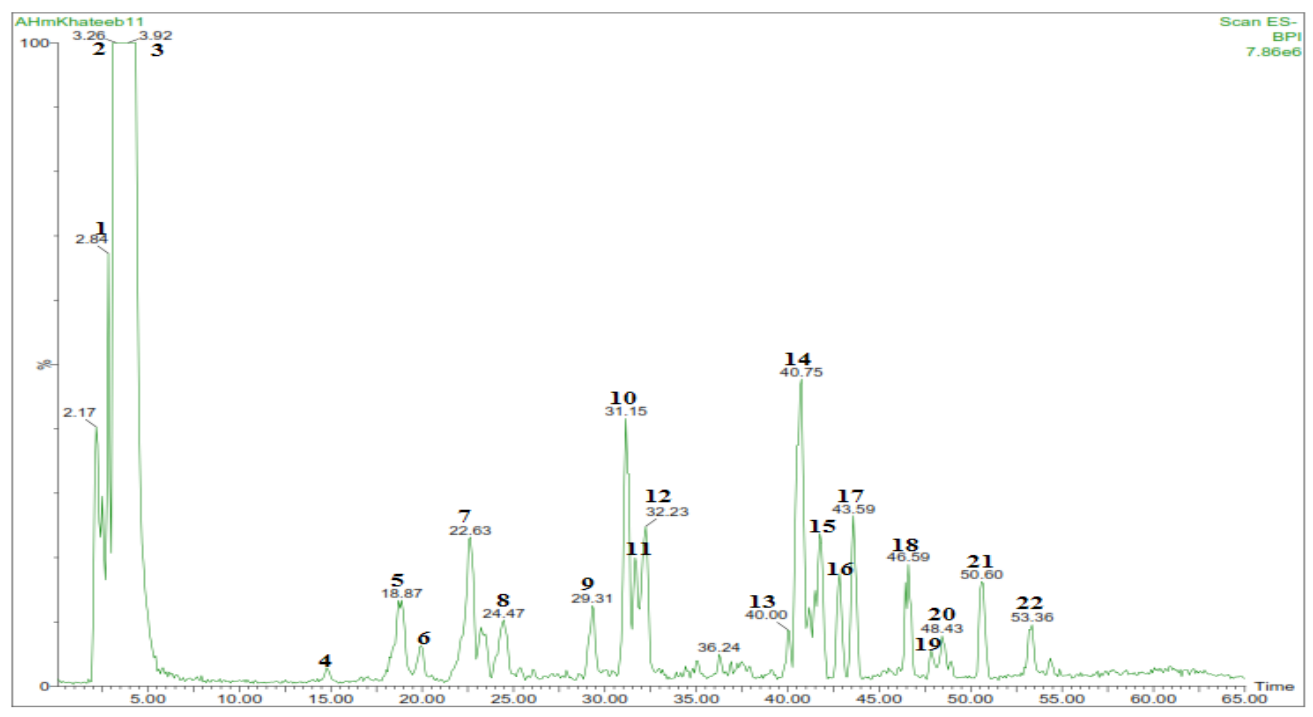

Fig. 1. LC-ESI-MS chromatogram of B. senegalensis .

pseudomolecular ion peak at $\mathrm{m} / \mathrm{z} 833[\mathrm{M}-\mathrm{H}]^{-}$and gave fragment ions $m / z 729,567,463,301$ that is due to the loss of benzoyl group [M-H-102]- then glucose moiety [M-H-102-162] and repeated the same group in the same manner, from our best of knowledge compounds $\mathbf{1 3}$ and $\mathbf{1 6}$ identified for the first time from nature.

The fragments of Peaks 12,15 are characterized for rhamnetin nucleus $(\mathrm{m} / \mathrm{z} 315,301)$; they appeared at molecular ion peak at $\mathrm{m} / z$ 639, 785 respectively, the fragmentation of the two peaks indicated that compound $\mathbf{1 2}$ is rhamentin-di-Oglucoside peak while compound $\mathbf{1 5}$ is rhamentin di- $O$ - glucoside- $O$-rhmanoside.

Peaks 18 - 22 are characterized for rhamnocitrin nucleus ( $\mathrm{m} / \mathrm{z} 299)$, peak 18 is a diglycoside compound with molecular ion peak $\mathrm{m} / \mathrm{z} 607$, the departure of both sugars with the presence of fragment at $m / z 299$ [M-H-146-162] only indicated that they are at the same position in the rhamnocitrin nucleus, while compound $\mathbf{2 1}$ is monoglucoside of rhamnocitrin. Peaks 19, 20 and 22 are rhamnocitrin acylated derivatives which were previously reported from the plant under investigation [8].

In vitro anticancer and antiviral activities.

Plant extracts show interesting anticancer effects on different cell lines yielding higher activity compared with pure natural and synthetic compounds. This remarkable effect is due to synergy between different compounds [19]. Among the important anticancer constituents, phenolic compounds, especially flavonoids. Kampferol, quercetin and their derivatives proved to be effective against numerous cancer cell lines [19]. The main components in the tested extract are phenolic acids and flavonoids.

The aqueous methanolic extract of $B$. senegalensis was tested for cytotoxic activity, (at concentrations between 0, 5, 12.5, 25, $50 \mu \mathrm{g}$ / $\mathrm{ml}$ ) against three tumor cell lines: HEPG2 (liver carcinoma cell line), MCF7 (breast carcinoma cell line) and HCT (colon carcinoma cell line) as flavonoids had reported having anticancer and antioxidant activities [20]. Results concluded that the in vitro cytotoxicity of the extract showed a moderate antitumor activity against the three cell lines HEPG2 $\left(\mathrm{IC}_{50} 24.6 \mu \mathrm{g} / \mathrm{ml}\right), \mathrm{MCF} 7\left(\mathrm{IC}_{50} 22.5\right.$ $\mu \mathrm{g} / \mathrm{ml})$ and $\mathrm{HCT}\left(\mathrm{IC}_{50} 40.3 \mu \mathrm{g} / \mathrm{ml}\right)$.

Antiviral activity of $B$. senegalensis aqueous methanolic extract was measured using plaque reduction assay; it showed $90 \%$ inhibition against H5N1viruses at concentration of $150 \mu \mathrm{g} / \mathrm{ml}$.

This is considered to be the first study deals with in vitro anticancer and antiviral activities of $B$. senegalensis and the results encourage further investigation to isolate and identify the bioactive compounds present in the extract.

\section{Acknowledgment}

The authors thank Prof. Dr. El-Sayed S. Abdel-Hameed (Chemistry Department, Faculty of Science, Taif University, Saudi Arabia) for measuring the mass spectra.

Egypt. J. Chem. 62, No. 1 (2019) 


\section{References}

1. Boulos L., Flora of Egypt, Al Hadara Puplishing, Vol.1, Cairo, Egypt, p. 174-175 (1999).

2. Morgan A. M., Lim C. H., and Kim Y. H., Lignans, cyclolignans and neolignans from the leaves of Boscia senegalensis (Pers.) Lam. ex Poir. Biochemical Systematics and Ecology, 59 (22), 226-228 (2015).

3. Khalafalla M. M., Daffalla H. M., Abdellatef E., Agabna E. and El-Shemy H. A., Establishment of an in vitro micropropagation protocol for Boscia senegalensis (Pers.) Lam. ex Poir. Journal of Zhejiang University Science B, 12(4), 303 (2011).

4. Dicko M. H., Searle-van Leeuwen M. J., Traore A. S., Hilhorst R. and Beldman G., Polysaccharide hydrolases from leaves of Boscia senegalensis. Applied Biochemistry and Biotechnology, 94(3), 225-241 (2001).

5. Sanon A., Garba M., Auger J. and Huignard J., Analysis of the insecticidal activity of methylisothiocyanate on Callosobruchus maculatus (F.)(Coleoptera: Bruchidae) and its parasitoid Dinarmus basalis (Rondani) (Hymenoptera: Pteromalidae). Journal of Stored Products Research, 38(2), 129-138 (2002).

6. Sakine M. N. A., Mahmout Y., Dijoux-Franca M. G., Gbenou J. and Moudachirou, M., In vitro antihyperglycaemic effect of glucocapparin isolated from the seeds of Boscia senegalensis (Pers.) Lam. ex Poiret. African Journal of Biotechnology, 11(23), 6345-6349 (2012).

7. Kjær A., Schuster A., Delaveau P. and Koudogbo, B., GlucosinolatS in Boscia senegalensis. Phytochemistry. (1973).

8. Morgan A. M., Kim J. H., Kim S. K., Lim C. H., and Kim Y. H., A New Flavonol Glycoside from the Leaves of Boscia senegalensis. Bull. Korean Chem. Soc, 35(12), 3447 (2014).

9. Mosmann T., Rapid colorimetric assay for cellular growth and survival: application to proliferation and cytotoxicity assays. Journal of Immunological Methods, 65(1-2), 55-63(1983).

10. Hayden F. G., Cote K. M. and Douglas R. G., Plaque inhibition assay for drug susceptibility testing of influenza viruses. Antimicrobial Agents and Chemotherapy, 17(5), 865-870 (1980).

11. Vichai V., and Kirtikara K., Sulforhodamine B colorimetric assay for cytotoxicity screening. Nature Protocols, 1(3), 1112-1116 (2006).

12. Plazonić A., Bucar F., Maleš Ž., Mornar A., Nigović B. and Kujundžić N., Identification and quantification of flavonoids and phenolic acids in burr parsley (Caucalis platycarpos L.), using high-performance liquid chromatography with diode array detection and electrospray ionization mass spectrometry. Molecules, 14(7), 2466-2490 (2009).

13. Sanchez-Rabaneda F., Jauregui O., LamuelaRaventos R. M., Bastida J., Viladomat F. and Codina C., Identification of phenolic compounds in artichoke waste by high-performance liquid chromatography-tandem mass spectrometry. Journal of Chromatography A, 1008(1), 57-72 (2003).

14. El-Hagrassy A. M., Elkhateeb A., Hussein S. R., Abdel-Hameed E. S. S. and Marzouk M. M., LCESI-MS profile, antioxidant activity and cytotoxic screening of Oligomeris linifolia (Vahl) Macbr. (Resedaceae). Journal of Applied Pharmaceutical Science, 7(8), 43-47 (2017).

15. Bianco G., Lelario F., Battista F.G., Bufo S.A., Cataldi T.R.I., Identification of glucosinolates in capers by LC-ESI-hybrid linear ion trap with Fourier transform ion cyclotron resonance mass spectrometry (LC-ESI-LTQ-FTICR MS) and infrared multiphoton dissociation. Journal of Mass Spectrometry, 47, 1160-1169 (2012).

16. Cao G., Fu Q., Zhang C., Wang H. and Chen S., Rapid characterization of 96 chemical constituents in Citri reticulatae folium (leaves of 'Fuju') using HPLC-DAD-ESI-MSn. J. Chin. Phar. Sci., 25, 91110 (2016).

17. Kang J., Price W. E., Ashton J., Tapsell L. C. and Johnson S., Identification and characterization of phenolic compounds in hydromethanolic extracts of sorghum wholegrains by LC-ESI-MSn. Food Chemistry, 211, 215-226 (2016).

18. Ibrahim L. F., Elkhateeb A., Marzouk M. M., Hussein S. R., Abdel-Hameed E. S. S. and Kassem M. E., Flavonoid investigation, LC-ESIMS profile and cytotoxic activity of Raphanus raphanistrum L.(Brassicaceae). Journal of Chemical and Pharmaceutical Research, 8(7), 786-793 (2016).

19. Carocho M. and CFR Ferreira, I. The role of phenolic compounds in the fight against cancer-a review. Anti-Cancer Agents in Medicinal Chemistry (Formerly Current Medicinal Chemistry-Anti-Cancer Agents), 13(8), 12361258 (2013).

20. Stauth, D., Studies Force New View On Biology Of Flavonoids. Oregon State University, USA (2007).

(Received 11/8/2018; accepted 29/8/2018) 


\section{تحليل LC-ESI-MS، الأنشطة المضادة للأور ام والفيروسات لمستخلص الميثانول المائى لتبات المخيط

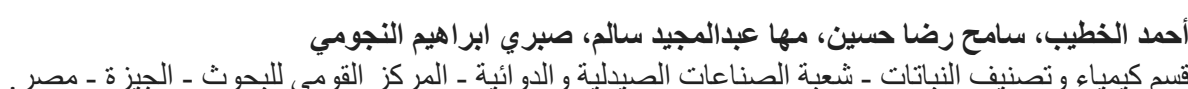

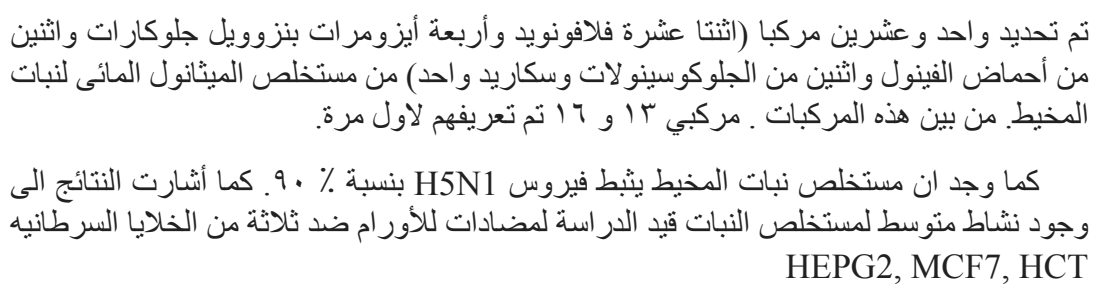

